\title{
Hydrological complexity supports high phytoplankton richness in the Doñana marshland (SW Spain)
}

\author{
I. Reyes $\cdot$ M. A. Casco $\cdot$ J. Toja $\cdot$ L. Serrano
}

(C) Springer Science+Business Media B.V. 2008

\begin{abstract}
Two hundred and twenty-four phytoplanktonic taxa were recorded in a riverine floodplain on the NE side of the Doñana marshland from September 2002 to 2004. This collection of 11 samples included 80 Bacillariophyceae (Diatoms), 71 Chlorophyta, 39 Cyanophyta, 19 Euglenophyta, 6 Chrysophyceae, 5 Cryptophyta, and 4 Dinophyceae. Fifty-five percent of the total taxa had a very low frequency of appearance $(<5 \%)$, while only three species appeared with a frequency $>90 \%$ (Monoraphidium contortum Komárková-Legnevorá, Cyclotella atomus Hustedt, and Nitzschia palea W. Smith). According to multivariate analyses, both temporal and spatial factors produced a pattern in the phytoplankton assemblages dominated by freshwater inputs during winter flooding, tidal inputs in summer, and transitional stages during the rest of the year. Spatial segregation of phytoplankton was likely due to differences in retention time and distance to water input. The main taxa involved in this
\end{abstract}

Guest Editors: U.M. Azeiteiro, I. Jenkinson \& M.J. Pereira Plankton Studies

I. Reyes · J. Toja $\cdot$ L. Serrano

Plant Biology and Ecology Department, University

of Sevilla, Sevilla, Spain

M. A. Casco $(\square)$

División Científica Ficología, Facultad de Ciencias

Naturales y Museo, UNLP, CONICET, La Plata,

Argentina

e-mail: casco@fcnym.unlp.edu.ar segregation were Chrysidalis sp. 1 (June 2003 and 2004), Chlamydomonas sp. 4 (September 2003), C. atomus (December 2003), and Tetradesmus aff. crocini (February 2004). The hydrologic complexity of the study area could account for this high taxa richness by promoting replacement and colonization episodes following seasonal changes in water source (freshwater versus tidal inputs).

Keywords Mediterranean coastal wetlands . Rice-pads · Guadiamar River

\section{Introduction}

Coastal wetlands under Mediterranean climate are largely influenced by hydrologic features, nutrient availability, and seasonality (Comín \& Valiela, 1993; Quintana \& Moreno-Amich, 2002; Nuccio et al., 2003). This kind of systems is difficult to study because they are very dynamic and subject to variable stages (Comín et al., 1999). Consequently, few publications on phytoplankton composition are available (Sabater \& Muñoz, 1990; Romo \& Miracle, 1994; Gilabert, 2001; Rodrigo et al., 2001; Puigserver et al., 2002; Villena \& Romo, 2003; López-Flores et al., 2006).

Changes in phytoplankton composition of Mediterranean coastal wetlands are often related to salinity (Puigserver et al., 2002), eutrophication (Sorokin 
et al., 1996; Villena \& Romo, 2003), and seasonality of temperature and light conditions (Romo \& Miracle, 1994). An annual seasonal pattern driven by marine and freshwater fluxes, often due to anthropic control, has been generally observed in Mediterranean coastal wetlands ( Rojo \& Miracle, 1989; Comín \& Valiela, 1993; Puigserver et al., 2002). Stagnation versus flushing cycles due to drainage of rice pads has also been reported to account for seasonal changes in phytoplankton assemblages (Romo \& Miracle, 1995). In other cases, the phytoplankton community of coastal wetlands with permanent confinement has been driven by hydrologic disturbances with no fix pattern (López-Flores et al., 2006). The influence of allochthonous flora is commonly overlooked in wetland studies (Romo, 1997) despite different water inputs that allow the colonization of organisms from different origins (Comín et al., 1999).

The present study was carried out in the NE Doñana marshland, located at the final stretch of the Guadiamar River. This site is subject to tidal flow from the Guadalquivir River estuary. Therefore, the hydrology of the study site is complex due to both natural and artificial water bodies receiving water inputs from different origins depending on the season (Serrano et al., 2006; Reyes et al., 2007). The objectives of this study are: (1) to relate hydrologic heterogeneity to phytoplankton richness, composition, and abundance; (2) to test whether phytoplankton assemblages follow spatial and/or temporal patterns by means of multivariate analysis; (3) to study the influence of colonization events on phytoplankton composition.

Study area

Doñana has a Mediterranean climate with Atlantic influence, generally classified as dry subhumid. Rainfall is quite variable, both within a year and over the years. About $80 \%$ of the rainfall yearly average $(580 \mathrm{~mm})$ falls between the end of September and the beginning of April. Summers are very dry and hot, while winters are short and mild. Water balance is generally deficient as rainfall exceeds evapotranspiration only during 3 to 4 months of the year.

About 23,000 ha of the Doñana marshland are preserved within the Doñana National Park and the Natural Park. The study site covers 250 ha of the final stretch of the Guadiamar River encroached by two parallel levees built in 1956 (Fig. 1). It includes natural and man-made waterways, isolated waterbodies, and playa-floodplains (locally named as
Fig. 1 Map of the Doñana National Park and location of the study site

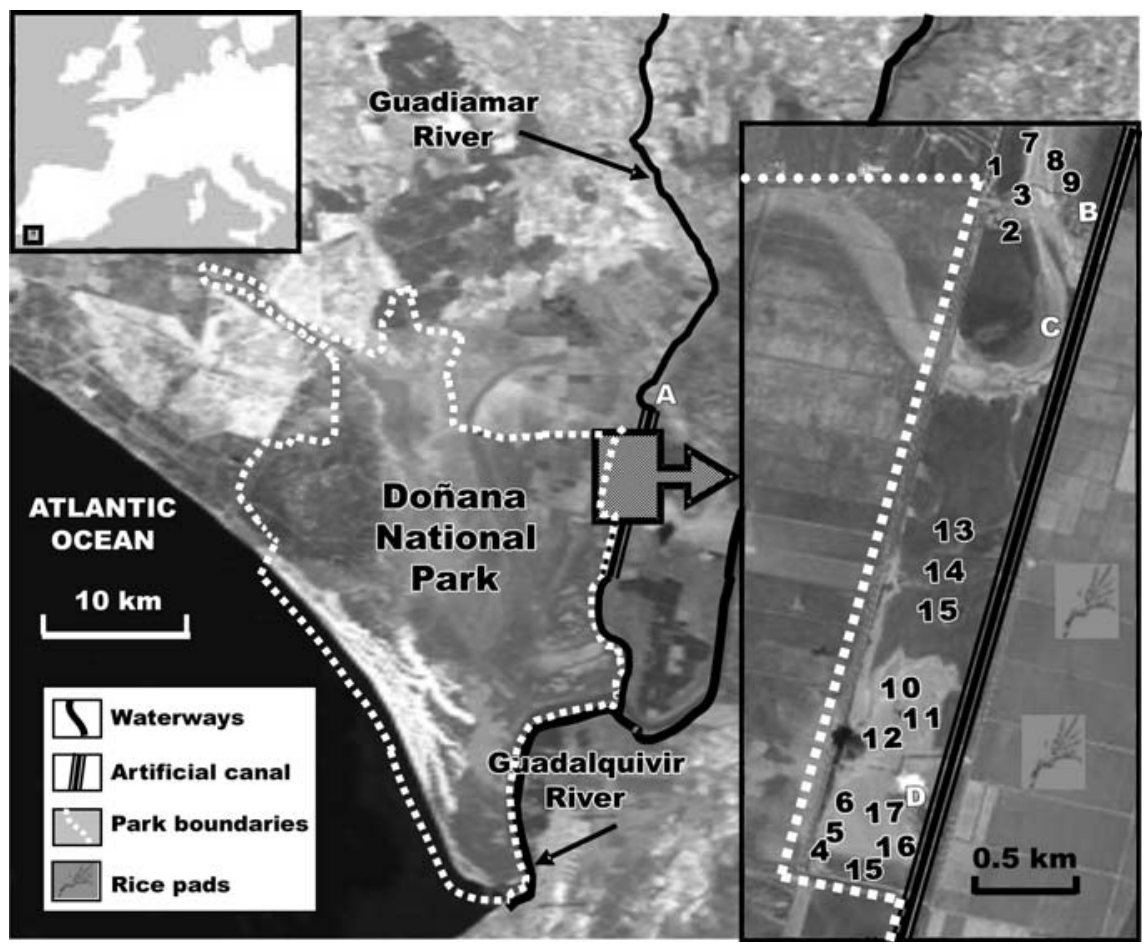


lucios), which give name to the whole site ("Lucio El Cangrejo Grande"). Most of the Guadiamar River water flow is diverted toward the Guadalquivir River estuary through an artificial canal, which is permanently connected to the study area by two inlets (Fig. 1: sites $\mathrm{B}$ and $\mathrm{C}$ ), seasonally by a floodgate (Fig. 1: site D), and occasionally during floods by the outflow of the Guadiamar River (Fig. 1: site A). Water in the study area is generally temporary and shallow except at the floodgate where water can reach up to $2 \mathrm{~m}$ in high-tide. Water temperature ranged from 8 to $30^{\circ} \mathrm{C}$, conductivity (at $25^{\circ} \mathrm{C}$ ) from 0.5 to $15.7 \mathrm{mS} \mathrm{cm}{ }^{-1}, \mathrm{Na}^{+}$was the dominant cation in the floodplains, while $\mathrm{Ca}^{2+}$ dominated in some waterways (Reyes et al., 2007). Water flowing through the artificial canal was usually turbid due to a high load of inorganic suspended matter largely composed of $\mathrm{CaCO}_{3}$ particles associated to $\mathrm{P}$ (Serrano et al., 2006). Vegetation of elevated areas was dominated by Sarcocornia fruticosa (L.) A.J. Scott, and Hordeum marinum Hudson, while aquatic emergent macrophytes (Phragmites australis (Cav.) Trin. ex Steudel, Scirpus maritimus L., Juncus subulatus Forsskall), and submerged macrophytes (Chara galioides DC, Callitriche truncata subsp. occidentalis (Rouy) Schotsman, Ranunculus peltatus subsp. fucoides (Freyn) Muñoz Garmendia, Ruppia drepanensis Tineo ex Guss) grew in flooded areas.

\section{Material and methods}

Twenty-one sampling sites were located within the study area and were sampled 11 times bimonthly during two consecutive hydrologic cycles: 2002/ 2003 and 2003/2004 (Fig. 1). Four sites corresponded to inlets, of which only three acted as outlets during floods or tidal flow (sites B, C and D), as site A was located upstream. Water samples of $125 \mathrm{ml}$ were preserved in situ with Lugol's iodine solution, and the determination of phytoplankton composition and abundance was performed in duplicates on fixed samples. Phytoplankton taxa were identified with an optical microscope. Abundance of phytoplankton cells was estimated with an inverted microscope following Utermöhl's method. Statistical analyses for community analyses (MDS, ANOSIM, SIMPER) were performed with PRIMER v5 based on quantitative samplings (three samplings in 2002/2003 and five in 2003/2004). An analog of the univariate ANOVA called ANOSIM was used to test for differences between multivariate samples from different sites or from different samplings. Similarity matrices of the multivariate samples were calculated using the Bray-Curtis coefficient after $\log$-transformation $[\log (x+1)]$ of the original taxa abundance to perform a non-metric multidimensional scaling (MDS). A SIMPER test was used to identify the taxa primarily providing the discrimination between samplings. Duplicates were averaged before calculations except to record cumulative richness. Rainfall data were obtained from the meteorological station of Palacio de Doñana (RBDCSIC).

\section{Results}

Phytoplankton cumulative richness (or total number of taxa) recorded in the study area was 224 taxa: 80 Bacillariophyceae (Diatoms), 71 Chlorophyta, 39 Cyanophyta, 19 Euglenophyta, 6 Chrysophyceae, 5 Cryptophyta, and 4 Dinophyceae. That is, $85 \%$ of the total taxa belonged to the sum of Bacillariophyceae (Diatoms), Chlorophyta, Cyanophyta, while each of the rest of groups amounted for less than $3 \%$ of the total taxa. Phytoplankton cumulative richness was significantly correlated with the number of samplings at each site $(r=0.765, P<0.05)$. The number of samplings was constrained by the availability of water at each site during the study. Therefore, the inlet sites, being permanent, accumulated the highest richness (115 taxa at site A).

Fifty-five percent of total taxa had a very low frequency of appearance $(<5 \%)$. Eighteen taxa appeared in at least $40 \%$ of total samplings (Table 1). Only three species (Monoraphidium contortum Komárková-Legnevorá, Nitzschia palea W. Smith, and Cyclotella atomus Hustedt) had a frequency of appearance $\geq 90 \%$, being also relatively abundant species. Consequently, frequency of appearance and average abundance were positively correlated $(r=0.789, P<0.01)$.

An ordination in MDS showed that phytoplankton assemblages were segregated into groups according to the number of samplings carried out during each cycle (Fig. 2A). This temporal segregation was stronger in 2002/2003 (ANOSIM test, $R=0.968$, 
Table 1 List of phytoplankton taxa with a frequency of appearance $\geq 40 \%$ showing average abundance (cell ml ${ }^{-1}$ )

\begin{tabular}{lll}
\hline Taxa & $\begin{array}{l}\text { Frequency } \\
(\%)\end{array}$ & $\begin{array}{l}\text { Average } \\
\text { abundance } \\
\left(\text { cell ml }{ }^{-1}\right)\end{array}$ \\
\hline Nitzschia palea W. Smith & 99 & $4.0 \times 10^{3}$ \\
Monoraphidum contortum & 96 & $4.0 \times 10^{3}$ \\
$\quad$ Komárková-Legnevorá & & \\
Cyclotella atomus Hustedt & 90 & $3.0 \times 10^{3}$ \\
Schroederia sp. & 80 & $1.0 \times 10^{3}$ \\
Nitzschia longissima Ralfs & 75 & $4.0 \times 10^{2}$ \\
Euglena variabilis Klebs & 72 & $2.0 \times 10^{2}$ \\
Monoraphidium circinale Nygaard & 70 & $3.0 \times 10^{2}$ \\
Navicula radiosa Kützing & 70 & $1.0 \times 10^{2}$ \\
Nitzschia acicularis W. Smith & 67 & $6.0 \times 10^{2}$ \\
Monoraphidium sp. & 59 & $3.0 \times 10^{2}$ \\
Scenedesmus tenuispina Chodat & 53 & $1.0 \times 10^{2}$ \\
Cryptomonas ovata Ehrenberg & 53 & $4.0 \times 10^{2}$ \\
Chlorococcum sp. & 52 & $2.0 \times 10^{2}$ \\
Chlamydomonas sp. 3 & 49 & $3.0 \times 10^{2}$ \\
Scenedesmus ecornis Chodat & 49 & $2.0 \times 10^{2}$ \\
Synechocystis sp. & 47 & $1.0 \times 10^{3}$ \\
Entomoneis alata Ehrenberg & 46 & 10 \\
Chlorella minutissima Fott \& Novak & 41 & $2.0 \times 10^{2}$ \\
\hline
\end{tabular}

$P<0.01)$ than in $2003 / 2004$ when five samplings were carried out $(R=0.718, P<0.01)$. In 2002/ 2003, phytoplankton assemblages showed a weak segregation within the April sampling between sites located in the northern and southern end of the study area $(R=0.617, P<0.01)$. Therefore, phytoplankton assemblages were basically arranged following temporal changes, while segregation according to spatial differences was evident only on certain occasions and occurred at the same time as temporal segregation (Fig. 2A). For example, the abundance of C. atomus was larger during September compared to June 2003, and in the northern rather than southern part of the study area during April 2003 (Fig. 2B). It is likely that $C$. atomus derived from the downstream drift of the Guadiamar River, which enters the study area from its northern end.

Few taxa contributed to the temporal segregation of each cycle according to a SIMPER test, which indicated that most taxa provided a very small contribution to the segregation among samplings (Table 2). Only eight taxa were involved in the characterization of each sampling with a contribution higher than $10 \%$ :

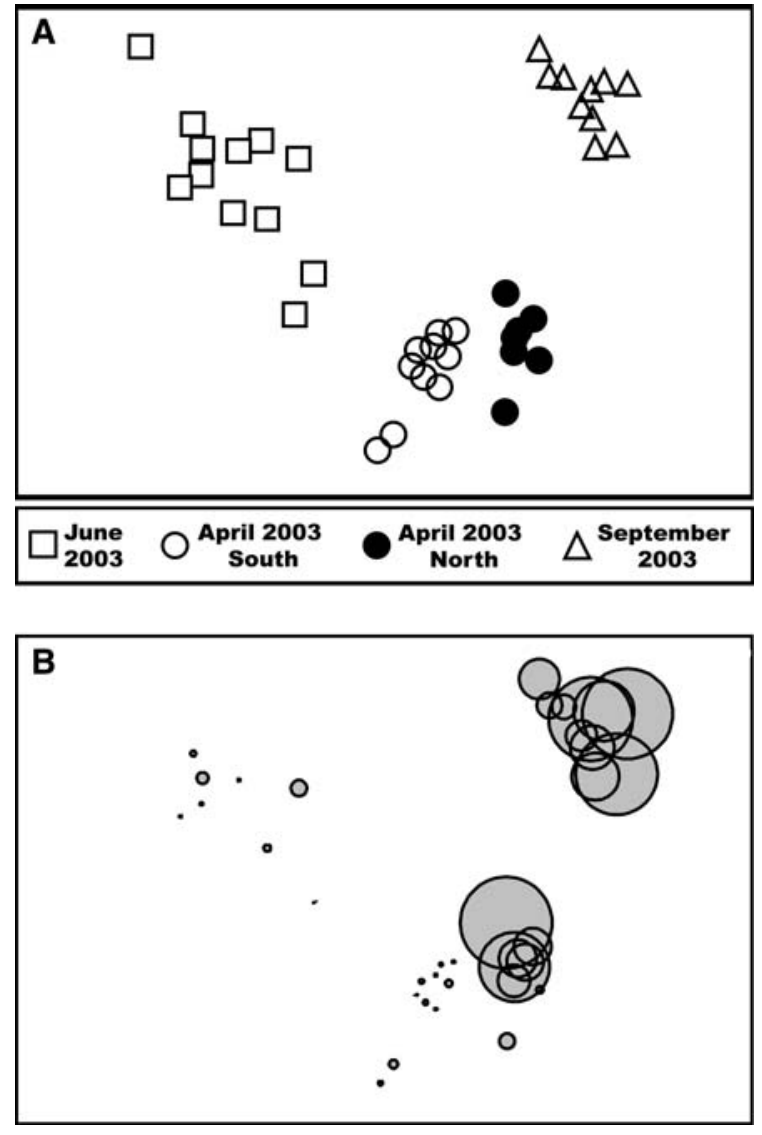

Fig. 2 (A) Ordination in MDS of phytoplankton assemblages of each site according to sampling during 2002/2003. North and South sites are distinguished in April 2003; (B) Size of bubbles represents relative abundance of Cyclotella atomus Hustedt at each site during 2002/2003

Chrysidalis sp. 1, C. atomus, Tetradesmus aff. crocini, Monoraphidium sp., M. contortum, Chroococcus aff. minutus, N. palea, and Chlamydomonas sp. 4. Only four taxa accounted for the dissimilarity among groups with a contribution of at least $10 \%$. The presence and abundance of Chrysidalis sp. 1 and Chlamydomonas sp. 4 differentiated the phytoplankton assemblages of June and September 2003, respectively, from the rest of samplings within 2002/2003, while C. atomus, $T$. aff. crocini., and Chrysidalis sp. 1 were responsible for the differences in December 2003, February 2004, and June 2004, respectively, within 2003/2004 (Table 2).

Abundance of main phytoplankton taxa ranged widely (Table 1). Some taxa maintained a relatively high abundance $\left(1.4 \times 10^{4}\right.$ cells ml $\left.^{-1}\right)$ throughout the study period (e.g., M. contortum), while others were more 
Table 2 List of phytoplankton taxa with a contribution above $10 \%$ to similarity within each sampling and dissimilarity among samplings

\begin{tabular}{|c|c|c|}
\hline Sampling & Similarity within sampling & Dissimilarity among samplings \\
\hline April 2003 & $\begin{array}{l}\text { Chroococcus aff. minutus } \\
\text { Nitzschia palea } \text { W. Smith } \\
\text { Monoraphidum contortum } \\
\text { Komárková-Legnevorá }\end{array}$ & None \\
\hline June 2003 & $\begin{array}{l}\text { Chrysidalis sp. } 1 \\
\text { Monoraphidum contortum } \\
\text { Komárková-Legnevorá } \\
\text { Chroococcus aff. minutus }\end{array}$ & Chrysidalis sp. 1 \\
\hline September 2003 & $\begin{array}{l}\text { Chlamydomonas sp. } 4 \\
\text { Nitzschia palea W. Smith } \\
\text { Cyclotella atomus Hustedt }\end{array}$ & Chlamydomonas sp. 4 \\
\hline December 2003 & $\begin{array}{l}\text { Cyclotella atomus } \text { Hustedt } \\
\text { Nitzschia palea } \mathrm{W} \text {. Smith }\end{array}$ & Cyclotella atomus Hustedt \\
\hline February 2004 & $\begin{array}{l}\text { Monoraphidum contortum } \\
\text { Komárková-Legnevorá } \\
\text { Tetradesmus aff. crocini } \\
\text { Nitzschia palea } \text { W. Smith }\end{array}$ & Tetradesmus aff. crocini \\
\hline April 2004 & $\begin{array}{l}\text { Monoraphidum contortum } \\
\text { Komárková-Legnevorá } \\
\text { Monoraphidium } \text { sp. } \\
\text { Nitzschia palea } \text { W. Smith }\end{array}$ & None \\
\hline June 2004 & $\begin{array}{l}\text { Chrysidalis } \text { sp. } 1 \\
\text { Nitzschia palea } \mathrm{W} . \text { Smith }\end{array}$ & Chrysidalis sp. 1 \\
\hline September 2004 & $\begin{array}{l}\text { Nitzschia palea W. Smith } \\
\text { Cyclotella atomus Hustedt }\end{array}$ & None \\
\hline
\end{tabular}

abundant at certain samplings: Chrysidalis sp. 1 reached $8.4 \times 10^{5}$ cells $\mathrm{ml}^{-1}$ in June 2003 . On some occasions, high taxa abundance was preceded and/or followed by a negligible number of cells. Average abundance of 18 taxa, which appeared at both the inlet and the inner sites at the same time, fluctuated widely along successive samplings, suggesting that they were likely the result of colonization events (Table 3). Maximum abundance of Chrysidalis sp. $1\left(8.4 \times 10^{5} \mathrm{cell} \mathrm{ml}^{-1}\right)$, Chlamydomonas sp. $4\left(3.1 \times 10^{5} \mathrm{cell} \mathrm{ml}^{-1}\right)$, and $T$. aff. crocini. $\left(8.3 \times 10^{4}\right.$ cell ml$\left.{ }^{-1}\right)$ occurred in June 2003 and 2004, September 2003, and February 2004, respectively. This high abundance contributed to the segregation of each of these samplings.

\section{Discussion}

Primary producers of coastal wetlands are expected to cope with wide variation in salinity, turbidity, and nutrient concentrations (Odum, 1988). Most phytoplankton taxa had a low frequency within the study area $(<5 \%)$, suggesting a rapid replacement of species. Only M. contortum, C. atomus, and N. palea had a frequency of appearance higher than $90 \%$. The first two species are typical of estuaries (Trigueros \& Orive, 2001) and N. palea has been recorded in the Guadiamar River (Toja et al., 2004). Most abundant taxa in the study period corresponded to the functional groups of Reynold's (Reynolds et al., 2002) classification D, J, and X1, which are indicative of shallow systems rich in nutrients.

The positive correlation between cumulative richness and number of samplings indicated that a longer study period and/or a higher frequency of samplings would be required to reach a more conclusive result on the total number of taxa and the rate of species replacement. Despite this limitation, cumulative richness per surface area was higher than in nearby waterways (Guadiamar River and Guadalquivir River estuary) and reached similar values to other Mediterranean wetlands (Reyes et al., 2007). The study 
Table 3 Average abundance of phytoplankton taxa appearing simultaneously at inlet and inner sites during each sampling

\begin{tabular}{|c|c|c|c|c|c|c|c|c|}
\hline Taxa & $\begin{array}{l}\text { April } \\
2003\end{array}$ & $\begin{array}{l}\text { June } \\
2003\end{array}$ & $\begin{array}{l}\text { September } \\
2003\end{array}$ & $\begin{array}{l}\text { December } \\
2003\end{array}$ & $\begin{array}{l}\text { February } \\
2004\end{array}$ & $\begin{array}{l}\text { August } \\
2004\end{array}$ & $\begin{array}{l}\text { June } \\
2004\end{array}$ & $\begin{array}{l}\text { September } \\
2004\end{array}$ \\
\hline $\begin{array}{l}\text { Aphanocapsa elachista } \\
\text { W. \& G. S. West }\end{array}$ & NG & NG & $1.0 \times 10^{3}$ & NG & NG & NG & NG & NG \\
\hline Aphanothece nidulans Richter & NG & NG & $1.7 \times 10^{3}$ & NG & NG & NG & NG & NG \\
\hline Anabaena torulosa Lagerheim & NG & NG & $1.0 \times 10^{2}$ & NG & NG & NG & NG & NG \\
\hline $\begin{array}{l}\text { Merismopedia warmingiana } \\
\text { Lagerheim }\end{array}$ & NG & NG & NG & NG & NG & NG & $3.0 \times 10^{3}$ & $1.0 \times 10^{3}$ \\
\hline Limnothrix aff. planctonica & NG & $1.0 \times 10^{2}$ & $2.2 \times 10^{3}$ & NG & 30 & NG & $\mathrm{NG}$ & NG \\
\hline Oscillatoria aff. rosea & 20 & 20 & 60 & NG & NG & NG & $3.0 \times 10^{2}$ & $5.7 \times 10^{3}$ \\
\hline $\begin{array}{l}\text { Synechococcus linearis } \\
\text { Kómarek }\end{array}$ & 80 & NG & NG & NG & NG & NG & $10^{2}$ & NG \\
\hline $\begin{array}{l}\text { Synechococcus vantieghemii } \\
\text { Bourrelly }\end{array}$ & NG & NG & 40 & NG & NG & 40 & $3.3 \times 10^{3}$ & 40 \\
\hline Chlamydomonas sp. 3 & $6.0 \times 10^{2}$ & NG & NG & NG & $1.0 \times 10^{3}$ & $3.0 \times 10^{2}$ & NG & $1.0 \times 10^{2}$ \\
\hline Chlamydomonas sp. 4 & NG & NG & $1.2 \times 10^{4}$ & NG & 30 & NG & NG & $5.0 \times 10^{2}$ \\
\hline $\begin{array}{l}\text { Coelastrum microporum } \\
\text { Nägeli }\end{array}$ & $3.4 \times 10^{3}$ & $3.0 \times 10^{2}$ & NG & NG & $3.0 \times 10^{2}$ & NG & 40 & NG \\
\hline Pyramimonas sp. & NG & NG & NG & NG & NG & $1.0 \times 10^{3}$ & 40 & NG \\
\hline Tetradesmus aff. crocini & $4.0 \times 10^{3}$ & NG & NG & $2.0 \times 10^{2}$ & $2.5 \times 10^{4}$ & 70 & NG & NG \\
\hline Rhodomonas minuta Skuja & NG & NG & NG & $3.3 \times 10^{2}$ & $1.0 \times 10^{2}$ & NG & $1.0 \times 10^{2}$ & NG \\
\hline Chrysidalis sp. 1 & NG & $1.5 \times 10^{5}$ & NG & NG & NG & 30 & $7.6 \times 10^{4}$ & NG \\
\hline $\begin{array}{l}\text { Fallacia pygmaea Stickle \& } \\
\text { Mann }\end{array}$ & 30 & $2.0 \times 10^{2}$ & $1.5 \times 10^{3}$ & NG & NG & 30 & $3.0 \times 10^{2}$ & $3.0 \times 10^{2}$ \\
\hline Nitzschia longissima Ralfs & $1.0 \times 10^{2}$ & $1.5 \times 10^{3}$ & $4.0 \times 10^{2}$ & $1.0 \times 10^{2}$ & $1.0 \times 10^{3}$ & 50 & 40 & 20 \\
\hline Ntizschia sigma W. Smith & NG & NG & $1.3 \times 10^{3}$ & NG & NG & NG & NG & 60 \\
\hline
\end{tabular}

NG, negligible

area included a large diversity of water bodies with different water duration that could provide a wide range of aquatic conditions for phytoplankton development. There were lotic and lentic systems of both artificial and natural origins: trenches, canals, drainage channels, floodplains, and ponds. They received water from different sources following seasonal and yearly changes. When rainfall is heavy, the overflow of the Guadiamar River floods most part of the study area during winter-spring. As freshwater flow decreases during spring-summer, tidal water from the estuary of the Guadalquivir River becomes the only source of water until rice pads are drained in September-October (Serrano et al., 2006).

This hydrologic complexity could support high phytoplankton richness by enhancing species replacement through colonization processes. Infrequent taxa generally appeared with low average abundances probably due to drifting, but some taxa showed intermittent peaks of large abundance, simultaneously at inner and inlet sites, which could account for diverse episodes of colonization. Some of these taxa were also responsible for segregation among samplings: Chrysidalis sp. 1 (June 2003 and 2004), Chlamydomonas sp. 4 (September 2003), and $T$. aff. crocini. (February 2004). It is likely that Chrysidalis sp. 1 arrived to the study area with the tidal flow. Chrysophyceans are a significant fraction of marine phytoplankton and can also reach high abundance in brackish Mediterranean wetlands (Sorokin et al., 1996; Cruz-Pizarro et al., 2003). $T$. aff. crocini has already been recorded in the Guadiamar River (Marín \& García-Novo, 2006), and so it may have arrived to the study area in large numbers through the overflow of the Guadiamar River during winter flooding. 
In the present study, the composition and abundance of phytoplankton assemblages were segregated basically following temporal changes (samplings). Occasionally, some taxa showed spatial changes (e.g., North-South distribution of C. atomus in April 2003), probably due to the direction of the overflow of the Guadiamar River during spring. The influence of temporal, rather than spatial variation, was also more relevant for the composition of phytoplankton in the Albufera of Valencia (Romo, 1991). In the present study, spatial distributions were likely caused by differences in distance to the water input and/or retention time. Similarly, Romo (1997) found that the phytoplankton composition of inlet channels draining the rice pads was different from the composition at the inner sites of the Albufera of Valencia. Moreover, phytoplankton composition at inlet sites can be expected to change more than at inner sites. When phytoplankton assemblages from inlet and inner sites were analyzed separately in a previous work, highest average diversity occurred at the inlet sites (Reyes et al., 2007).

Taken into account the colonization processes, we conclude that phytoplankton assemblages were largely influenced by seasonal changes due to the arrival of water from different sources to the study area: freshwater input in winter (from the Guadiamar River) versus tidal water in summer (from the estuary of the Guadalquivir River). Transient stages occurred when no particular taxa contributed significantly to segregation (April 2003 and 2004, and September 2004). The fact that the freshwater influence was only evident in the segregation observed in 2003/2004 could be due to the higher amount of rainfall collected during that cycle $(755 \mathrm{~mm})$, which brought about a larger increase of river overflow, compared to the previous cycle $(510 \mathrm{~mm})$. Phytoplankton cumulative richness was relatively high despite poorer water quality than in other areas of the Doñana marshland (Serrano et al., 2006), and despite hydrologic variability being partly caused by anthropic control (rice pads, diversion of the overflow of the Guadiamar River through canals, floodgates, etc).

Acknowledgements We are very grateful to Pilar and Julio, to the rangers of Doñana Natural Park, and to our colleagues Gonzalo Martin, Arantza Arechederra, Marta Reina, David León, Virgilio Hermoso, Paco Blanco, and Pepe Prenda. This work was partly founded by the Consejería de Medio Ambiente, Junta de Andalucía.

\section{References}

Comín, F. A., F. Menéndez, J. A. Romero, O. Hernández, M. Martínez \& A. Chacón, 1999. Indicadores ecológicos y herramientas para la gestión de ecosistemas acuáticos en la zona costera. Limnetica 16: 61-68.

Comín, A. \& I. Valiela, 1993. On the controls of phytoplankton abundance and production in coastal lagoons. Journal of Coastal Research 9: 895-906.

Cruz-Pizarro, L., I. De Vicente, E. Moreno-Ostos, V. Amores \& K. El Mabrouki, 2003. Estudios de diagnósticos y viabilidad en el control de la eutrofización de las aguas de la Albufera de Adra. Limnetica 22: 135-154.

Gilabert, J., 2001. Seasonal plankton dynamics in a Mediterranean hypersaline coastal lagoon: the Mar Menor. Journal of Plankton Research 23: 207-217.

López-Flores, R., D. Boix, A. Badosa, S. Brucet \& X. D. Quintana, 2006. Pigment composition and size distribution of phytoplankton in a confined Mediterranean salt marsh ecosystem. Marine Biology 149: 1313-1324.

Marín, C. \& F. García-Novo, 2006. Doñana. Water and Biosphere. Spanish Ministry of Environment, Madrid.

Nuccio, C., C. Melillo, L. Massia \& M. Innamorati, 2003. Phytoplankton abundance, community structure and diversity in the eutrophicated Orbetello lagoon (Tuscany) from 1995 to 2001. Oceanologica Acta 26: 15-25.

Odum, W. E., 1988. Comparative ecology of tidal freshwater and salt marshes. Annual Review of Ecology and Systematics 19: 147-176.

Puigserver, M., G. Ramon \& G. Moya, 2002. Spatial and temporal distribution of phytoplankton in a Mediterranean Estuarine Canal System. Journal of Coastal Research 18: 39-51.

Quintana, X. D. \& R. Moreno-Amich, 2002. Phytoplankton composition of Empordá salt marshes and its response to freshwater flux regulation. Journal of Coastal Research 36: 581-590.

Reyes, I., G. Martín, M. Reina, A. Arechederra, L. Serrano, M. A. Casco \& J. Toja, 2007. Phytoplankton from NE Doñana marshland ("El Cangrejo Grande", Doñana Natural Park, Spain). Limnetica 26: 307-318.

Reynolds, C. S., V. Huszar, C. Kruk, L. Naselli-Flores \& S. Melo, 2002. Towards a functional classification of the freshwater phytoplankton. Journal of Plankton Research 24: 417-428.

Rodrigo, M. A., X. Armengol-Díaz, R. Oltra, M. J. Dasí \& W. Colom, 2001. Environmental variables and planktonic communities in two ponds of El Hondo wetland (SE Spain). International Review of Hydrobiology 86: 299-315.

Rojo, C. \& M. R. Miracle, 1989. Phytoplankton fluctuations during an annual cycle in the coastal lagoon of Cullera (Spain). Internationale revue der Gesamten Hydrobiologie 74: 179-194.

Romo, S., 1991. Estudio del fitoplancton de la Albufera de Valencia, una laguna hipertrófica y somera, entre 1980 y 1988. PhD Thesis, University of Valencia, Spain.

Romo, S., 1997. Importance of allochthonous phytoplankton in a coastal freshwater lake. Verhandlungen Internationale Vereinigung Limnologie 26: 610-614. 
Romo, S. \& M. R. Miracle, 1994. Population dynamics and ecology of subdominant phytoplankton species in a shallow hypertrophic lake (Albufera of Valencia, Spain). Hydrobiologia 273: 37-56.

Romo, S. \& M. R. Miracle, 1995. Diversity of the phytoplankton assemblages of a polymictic hypertrophic lake. Archiv für Hydrobiologie 132: 363-384.

Sabater, S. \& I. Muñoz, 1990. Successional dynamics of the phytoplankton in the lower part of the river Ebro. Journal of Plankton Research 12: 573-592.

Serrano, L., M. Reina, G. Martín, I. Reyes, A. Arechederra, D. León \& J. Toja, 2006. The aquatic systems of Doñana (SW Spain): watersheds and frontiers. Limnetica 25: 11-32.

Sorokin, Y. I., F. Dallocchio, F. Gelli \& L. A. Pregnolato, 1996. Phosphorus metabolism in anthropogenically transformed lagoon ecosystems: the Comacchio lagoons (Ferrara, Italy). Journal of Sea Research 35: 243-250.

Toja, J., G. Martín, E. Alcalá, C. Solá, A. Plazuelo, M. D. Burgos \& I. Reyes, 2004. Efecto de la contaminación minera sobre el perifiton del río Guadiamar. Limnetica 23: 315-329.

Trigueros, J. M. \& E. Orive, 2001. Seasonal variations of diatoms and dinoflagellates in a shallow, temperate estuary, with emphasis on neritic assemblages. Hydrobiologia 444: 119-133.

Villena, M. J. \& S. Romo, 2003. Phytoplankton changes in a shallow Mediterranean lake (Albufera of Valencia, Spain) after sewage diversion. Hydrobiologia 506-509: 281-287. 